\title{
Cytosine methylation of sperm DNA in horse semen after cryopreservation
}

\section{Christine Aurich ${ }^{a}, *$, Bettina Schreiner ${ }^{a}$, Natascha Ille ${ }^{a}$, Marco Alvarenga ${ }^{b}$, Dragos Scarlet $^{\mathrm{c}}$}

\footnotetext{
a Artificial Insemination and Embryo Transfer, Department for Small Animals and Horses, Vetmeduni Vienna, Vienna, Austria

${ }^{\mathrm{b}}$ Department of Animal Reproduction \& Veterinary Radiology, Faculty of Veterinary Medicine, FMVZ - Sao Paulo State University UNESP, Botucatu, Brazil

${ }^{\mathrm{c}}$ Obstetrics, Gynecology, Andrology, Department for Small Animals and Horses, Vetmeduni Vienna, Vienna, Austria
}

\section{A R T I C L E I N F O}

\section{Article history:}

Received 2 September 2015

Received in revised form 26 April 2016

Accepted 26 April 2016

\section{Keywords:}

Horse

Semen

Cryopreservation

DNA methylation

\begin{abstract}
A B S T R A C T
Semen processing may contribute to epigenetic changes in spermatozoa. We have therefore addressed changes in sperm DNA cytosine methylation induced by cryopreservation of stallion semen. The relative amount of 5-methylcytosine relative to the genomic cytosine content of sperm DNA was analyzed by ELISA. In experiment 1 , raw semen $(n=6$ stallions, one ejaculate each) was shock-frozen. Postthaw semen motility and membrane integrity were completely absent, whereas DNA methylation was similar in raw $(0.4 \pm 0.2 \%)$ and shock-frozen $(0.3 \pm 0.1 \%)$ semen (not significant). In experiment 2 , three ejaculates per stallion $(n=6)$ were included. Semen quality and DNA methylation was assessed before addition of the freezing extender and after freezing-thawing with either Ghent $(G)$ or BotuCrio (BC) extender. Semen motility, morphology, and membrane integrity were significantly reduced by cryopreservation but not influenced by the extender (e.g., total motility: G $69.5 \pm 2.0$, BC $68.4 \pm 2.2 \%$; $\mathrm{P}<0.001$ vs. centrifugation). Cryopreservation significantly $(P<0.01)$ increased the level of DNA methylation (before freezing $0.6 \pm 0.1 \%$, postthaw G $6.4 \pm 3.7$, BC $4.4 \pm 1.5 \%$; $\mathrm{P}<0.01$ ), but no differences between the freezing extenders were seen. The level of DNA methylation was not correlated to semen motility, morphology, or membrane integrity. The results demonstrate that semen processing for cryopreservation increases the DNA methylation level in stallion semen. We conclude that assessment of sperm DNA methylation allows for evaluation of an additional parameter characterizing semen quality. The lower fertility rates of mares after insemination with frozen-thawed semen may at least in part be explained by cytosine methylation of spermDNA induced by the cryopreservation procedure.
\end{abstract}

(c) 2016 Elsevier Inc. All rights reserved.

\section{Introduction}

Because of the globalization of horse breeding, the significance of semen cryopreservation in horses is steadily increasing [1,2]. Although frozen semen is produced from a large number of stallions [3], with regard to cryosurvival of

\footnotetext{
* Corresponding author. Tel.: +43 1 250776400; fax: +43 1250775491. E-mail address: christine.aurich@vetmeduni.ac.at (C. Aurich).
}

semen high variability exists among stallions [4]. Only approximately $50 \%$ of the stallions are considered acceptable for production of cryopreserved semen [3]. Cryoinjury of spermatozoa is mainly represented by membrane damage due to physical stress, i.e., osmotic stress due to extracellular ice formation, phase transition from liquid to crystalline and oxidative stress [4-6]. Moreover, cryopreservation also induces DNA fragmentation independent of membrane damage [7,8]. Cryopreserved semen of good in vitro quality may render low conception rates in the field 
[3]. Nevertheless, the possibility to predict semen fertility on the basis of laboratory assessment is still limited. Recently, aberrant methylation of sperm DNA has been suggested to affect fertilization and development of the preimplantation embryo [9-11]. Moreover, cryopreservation of semen contributes to dramatic changes in messenger RNA expression of epigenetic-related genes [12]. Assessment of DNA methylation has therefore been suggested as a new approach to evaluate the ability of spermatozoa to fertilize the oocyte and lead to normal embryo development [9].

In mammalian cells, epigenetic changes include DNA methylation, posttranslational histone modifications, chromatin remodeling, and production of small noncoding RNAs [13]. Among those, DNA methylation attracts specific interest for the assessment of epigenetic changes and is defined as the stable addition of a methyl group to cytosine, mainly in enriched CG (cytosine guanine) regions of the DNA, also described as CpG (5'-C-phosphate- $\left.-\mathrm{G}-3^{\prime}\right)$ islands. Methylation can represent a response to environmental cues and may modify gene expression [13]. Epigenetic modifications are generally removed and reestablished from one generation to the next [14]. During male germline development, paternal DNA methylation marks are erased and established through waves of demethylation and de novo methylation [15]. To the best of our knowledge, no information on DNA methylation of equine sperm is available so far.

In the present study, we have followed the hypothesis that DNA methylation of stallion sperm is affected by cryopreservation. We have therefore analyzed global 5-methylcytosine in DNA of equine semen before and after freezing.

\section{Material and methods}

\subsection{Experimental animals and semen collection}

The experiment was done in accordance with experimental animal legislation in Austria. Six healthy fertile Shetland pony stallions aged between 8 and 23 years $(15.5 \pm 3.2)$ with three stallions being younger than 12 and three older than 20 years of age were used for the study. Stallions' weight was between 116.0 and $183.5 \mathrm{~kg}$ (mean $156.0 \pm 6.7 \mathrm{~kg}$ ). All stallions were kept in groups in loose barns, fed hay twice daily, and had free access to water and minerals. Semen from the stallions was collected at regular intervals, i.e., two or three times per week with a Hannover artificial vagina (Minitube, Tiefenbach, Germany) on a dummy as described [16]. For semen collection, stallions were exposed to a teaser mare until erection and readiness to mount, followed by mounting of the dummy.

\subsection{Experimental design}

\subsubsection{Experiment 1}

For the first experiment, one ejaculate per stallion $(n=6)$ was collected. Immediately after semen collection, the gel fraction of the ejaculate was removed. Semen was filtered through sterile gauze, and volume, sperm concentration, total sperm count, as well as percentage of motile, progressively motile, and membrane-intact spermatozoa were evaluated (see Section 2.3 for further details). The ejaculate was then divided in two portions: from one portion, DNA was extracted without further semen processing, whereas from the second portion, $1.5-\mathrm{mL}$ semen were filled in a tube and plunged into liquid nitrogen $\left(-196{ }^{\circ} \mathrm{C}\right)$ for 15 minutes before thawing at $38{ }^{\circ} \mathrm{C}$ for 1 minute (shock-frozen semen), followed by DNA extraction.

\subsubsection{Experiment 2}

From each of the six stallions, three ejaculates were collected at 1-week intervals. Immediately after semen collection, the gel fraction of the ejaculate was removed. Semen was filtered through sterile gauze; and volume, sperm concentration, total sperm count, and percentage of motile, progressively motile, membrane-intact, and morphological intact spermatozoa were evaluated (see Section 2.3 for further details). Ejaculates were split in three aliquots. Two aliquots were diluted with EquiPlus extender (Minitube) and one with BotuSemen extender (Nidacon International, Mölndal, Sweden) to a concentration of 100 to 200 spermatozoa/mL, dependent on the volume and availability of semen, and filled into a sterile centrifugation tube. Centrifugation was performed with Androcoll (Minitube) for 20 minutes at $25{ }^{\circ} \mathrm{C}$ at $800 \times g$ (Centrifuge $5804 \mathrm{R}$, Eppendorf, Hamburg, Germany) for removal of somatic cells. The supernatant was discarded and the semen pellet submitted to further processing. One of the aliquots diluted with Equiplus was used for analysis of semen quality and DNA extraction before freezing (final concentration: 50 million spermatozoa $/ \mathrm{mL}$ ). The second aliquot was cryopreserved with Ghent $(G)$ extender, and the third aliquot cryopreserved with BotuCrio (BC) extender. In these aliquots, semen analysis and DNA extraction was performed after thawing of one straw each after at least 4 weeks of storage in liquid nitrogen $\left(-196^{\circ} \mathrm{C}\right)$.

\subsection{Experimental procedures}

\subsubsection{Cryopreservation and thawing of semen}

Processing of semen for cryopreservation was done at room temperature $\left(20^{\circ} \mathrm{C}\right)$. After centrifugation of extended semen, the supernatant was removed until approximately $1 \mathrm{~cm}$ above the surface of the sperm pellet. The sperm pellet was resuspended with the cryopreservation extender at a $1: 1$ ratio. The semen was filled in $0.5-\mathrm{mL}$ straws and sealed automatically at room temperature (MPP Uno, Minitube). Straws were placed on a rack into the freezing chamber of a computer-controlled rate freezer at $20{ }^{\circ} \mathrm{C}$ (IceCube $14 \mathrm{M}$; Sylab, Purkersdorf, Austria). Semen was first cooled to $5^{\circ} \mathrm{C}$ with a cooling rate of $0.3{ }^{\circ} \mathrm{C} / \mathrm{min}$, subsequently within 3 minutes to $-25^{\circ} \mathrm{C}\left(10^{\circ} \mathrm{C} / \mathrm{min}\right)$ and finally to $-140{ }^{\circ} \mathrm{C}$ with a cooling rate of $25{ }^{\circ} \mathrm{C} / \mathrm{min}$. Straws were removed from the chamber and plunged directly into liquid nitrogen in which they were stored for at least 4 weeks before thawing at $38^{\circ} \mathrm{C}$ for 15 seconds. Before further analysis, semen was held at room temperature for 15 minutes.

\subsubsection{Semen analysis}

Semen analysis was always performed by an experienced technician blinded to semen treatment. Sperm 
concentration was measured by Nucleocounter SP-100 (Chemometec, Allerod, Denmark) as described [16], and total sperm count was calculated from volume and sperm concentration. The percentage of motile, progressively motile, and membrane-intact spermatozoa was evaluated by computer-assisted sperm analysis (Spermvision, Minitube) as described [17-21]. For this purpose, the final concentration was adjusted to $50 \times 10^{6}$ sperm $/ \mathrm{mL}$ either with EquiPlus extender in the case of raw semen or with the centrifugation extender in cryopreserved semen.

For motility analysis, 30 frames per field were evaluated. To select cells from debris, the camera recognizes the position of the sperm heads in successive frames. At least seven fields per sample with approximately 100 cells per field were evaluated. Spermatozoa with average orientation change less than $8 \mu \mathrm{m}$ were considered immotile. Spermatozoa with curvilinear velocity greater than or equal to $10 \mu \mathrm{m} / \mathrm{s}$, distance straight line greater than or equal to $6 \mu \mathrm{m}$, and radius greater than or equal to $15 \mu \mathrm{m}$ were considered progressively motile $[17,20]$. For assessment of sperm membrane integrity, $100 \mu \mathrm{L}$ of semen were mixed with $2 \mu \mathrm{L}$ of SYBR-14/PI and incubated for 10 minutes at room temperature in darkness. One droplet was placed onto a glass slide, covered with a glass coverslip, and evaluated by fluorescence microscopy at magnification $\times 400$ (Olympus AX70, Olympus, Vienna, Austria; U-MWB filter block, BP420-480 excitation filter, BA515 suppressor filter, dichromatic mirror: DM500). At least 15 fields were evaluated, and the average value was calculated by the computer-assisted sperm analysis system. Results are given as percent of membrane intact cells. Sperm morphology was evaluated in an unstained wet mount preparation. Semen was fixed in buffered formol saline (1:4 ratio). At least 200 spermatozoa were checked for morphologic aberrations under a microscope at $\times 1000$ magnification with oil immersion as described [22]. Evaluation of sperm morphology was performed as described for equine spermatozoa [23] with slight modifications [20].

\subsubsection{DNA extraction}

DNA extraction was done as published by [24]. Semen was washed twice by the addition of $70 \%$ ethanol $(500 \mu \mathrm{L})$, centrifugation for 5 minutes at 15,500 $\times \mathrm{g}$ and removal of the supernatant. Then, $500 \mu \mathrm{L}$ lysis buffer (1-M Tris- $\mathrm{HCl} \mathrm{pH} 8.0$; $3-$ $\mathrm{M} \mathrm{NaCl}$; 0.5-M EDTA; $20 \%$ sodium dodecyl sulfate), $2.5-\mu \mathrm{L}$ Triton-X100 (0.5\%), 21- $\mu$ L DTT (dithiothreitol; $1 \mathrm{M}$ ), and 40- $\mu \mathrm{L}$ proteinase $\mathrm{K}(10 \mathrm{mg} / \mathrm{mL})$ were added. The samples were well mixed and incubated at $50{ }^{\circ} \mathrm{C}$ overnight in a thermoshaker. Tubes were centrifuged for 10 minutes at $15,500 \times \mathrm{g}$ at room temperature, and the supernatant was transferred into a new $1.5-\mathrm{mL}$ tube. Thereafter, $1-\mu \mathrm{L}$ glycogen $(20 \mathrm{mg} / \mathrm{mL})$ and $10 \%$ (v:v) NaAc (3 M) were added and gently mixed. Ice cold absolute ethanol (200\% v:v) was added, and the samples were precipitated at $-80{ }^{\circ} \mathrm{C}$ for 1 to 2 hours. The tubes were subsequently centrifuged for 20 minutes at $15,500 \times g$ at room temperature and the supernatant discarded. The DNA was washed by dispensing the pellet in $500-\mu \mathrm{L}$ ethanol (75\%) and centrifuged for 10 minutes at $15,500 \times g$ at room temperature. The samples were dried until ethanol evaporated, and finally, the DNA pellet was dissolved in Tris-EDTA -buffer overnight at $4{ }^{\circ} \mathrm{C}$. The samples were stored at $-20^{\circ} \mathrm{C}$ until further analysis.

\subsubsection{DNA methylation analysis}

Methylated DNA was detected using an ELISA with a monoclonal antibody sensitive and specific for 5methylcytosine and a horseradish peroxidase conjugate as secondary antibody (5-mC DNA ELISA Kit, Zymo Research, Irvine, CA, USA). The level of 5-mC in DNA is reported as the amount of methylated cytosine relative to the cytosine genomic content (\%). The capture antibody had no cross-reactivity with 5-hmC and unmethylated cytosine. DNA concentration was determined spectrophotometrically (Biophotometer plus, Eppendorf). An aliquot of the sample containing 100-ng DNA was added to the 5-mC coating buffer and brought to a final volume of $100 \mu \mathrm{L}$. All samples and controls were denaturated at $98{ }^{\circ} \mathrm{C}$ for 5 minutes in a thermocycler and immediately cooled on ice for 10 minutes. Controls and samples were added to the ELISA plate and incubated at $37{ }^{\circ} \mathrm{C}$ for one hour. After discarding the coating buffer, the wells were washed three times with the 5-mC ELISA buffer and incubated again with $200 \mu \mathrm{L}$ of 5 -mC ELISA buffer at $37{ }^{\circ} \mathrm{C}$ for 30 minutes. The buffer was discarded from the wells, and the samples were incubated with the antibody mix at $37^{\circ} \mathrm{C}$ for one hour. The antibody mix consisted of the 5-mC ELISA Buffer, anti5-methylcytosine and the secondary antibody in a ratio $1: 2000: 1000$. After incubation, the antibody mix was discarded, and $100-\mu \mathrm{L}$ horseradish peroxidase was added to each well. The absorbance was measured at $405 \mathrm{~nm}$ with the ELx808 Ultra microplate reader (BioTek Instruments, Winooski, VT, USA).

\subsection{Statistical analysis}

For statistical analysis, the computer software SPSS version 22 (IBM-SPSS, Armonck, NY, USA) was used. A P-value less than 0.05 was considered significant. As not all variables were normally distributed, data were log-transformed before analysis. In experiment 1 , the general linear model for repeated measures with semen processing (raw semen vs. shock-frozen semen) as within subject factor was used. In experiment 2 , the general linear model for repeated measures with semen processing (before freezing, cryopreservation Ghent extender, and cryopreservation BotuCrio extender) as within subject factor, stallion as between subject factor, and age-group (stallions $<12$ years vs. $>20$ years) as covariate was applied. If significant differences existed, Duncan's test was used for post hoc analysis. Spearman-Rho correlation test was used for analysis of correlations among the different parameters. Data given are means \pm standard error of mean.

\section{Results}

\subsection{Experiment 1}

With regard to semen volume $(22.3 \pm 6.2 \mathrm{~mL})$, concentration $\left(203 \pm 38 \times 10^{6} / \mathrm{mL}\right)$, and total sperm count $\left(3.8 \pm 0.7 \times 10^{9}\right)$, the ejaculates included into this experiment were in the physiological range for healthy Shetland pony stallions. In shock-frozen semen, motility was completely absent (raw: motility $80.2 \pm 10.8$, progressive 
motility $69.9 \pm 11.8 \%$; shock-frozen: motility $0.0 \pm 0.0$, progressive motility $0.0 \pm 0.0 \%$; $\mathrm{P}<0.01$ ), and membrane integrity dropped close to zero (raw: $82.5 \pm 8.9 \%$, shock-frozen: $0.9 \pm 0.2 \% ; \mathrm{P}<0.001)$. In contrast, DNA methylation was similar in raw $(0.4 \pm 0.2 \%)$ and shockfrozen $(0.3 \pm 0.1 \%)$ semen (not significant).

\subsection{Experiment 2}

With regard to semen volume $(28.1 \pm 8.8 \mathrm{~mL})$, concentration $\left(217 \pm 23 \times 10^{6} / \mathrm{mL}\right)$, and total sperm count $\left(3.7 \pm 0.3 \times 10^{9}\right)$, all ejaculates were in the physiological range for healthy Shetland pony stallions. Cryopreservation of semen significantly reduced semen motility, morphology, and membrane integrity $(\mathrm{P}<0.001)$, but no differences between cryopreservation extenders were seen with the exception of sperm morphology that was slightly but significantly $(\mathrm{P}<0.05)$ higher in semen frozen with $\mathrm{BC}$ extender (see Table 1 ). The effect of cryopreservation was significantly affected by stallion $(\mathrm{P}<0.05)$. In contrast, cryopreservation significantly $(\mathrm{P}<0.05)$ increased the level of DNA methylation in comparison to semen before freezing, but no significant effect of stallion on DNA methylation existed (Table 1, Fig. 1). No effects of stallion age on any of these parameters were found. The level of DNA methylation was not correlated to semen motility, morphology, or membrane integrity, but highly significant correlations among these standard laboratory parameters existed (Table 2).

\section{Discussion}

In the present study, we could demonstrate that cytosine methylation of sperm DNA in raw equine semen is low but is significantly increased by cryopreservation. To the best of our knowledge, no information on sperm DNA methylation in horses has been available so far. The range of cytosine hypermethylation in sperm DNA that was detected in response to freezing-thawing showed a wide variation

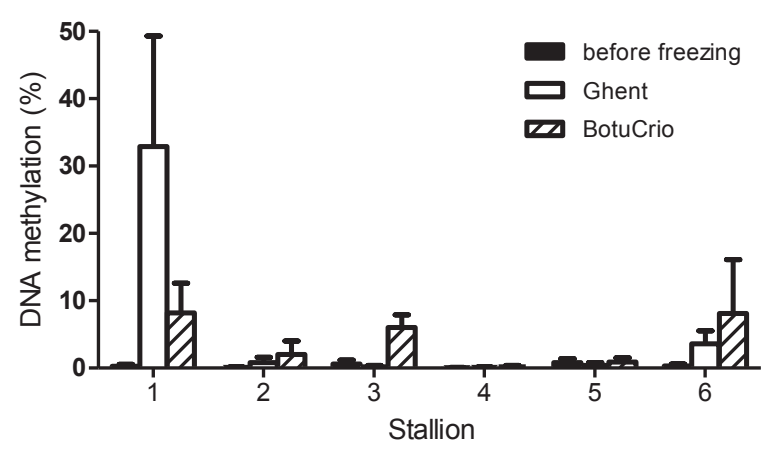

Fig. 1. DNA methylation (\%) in semen before freezing and in frozen-thawed semen after cryopreservation with Ghent or BotuCrio extender in individual stallions ( $\mathrm{n}=6, \mathrm{n}=3$ ejaculates per stallion). Values are presented as means + standard error of the mean.

among stallions despite the fact that all stallions had good or excellent semen motility and membrane integrity after freezing-thawing. Together with the fact that none of the routine laboratory parameters correlated with DNA methylation, this finding suggests that assessment of DNA methylation may be a valuable additional end point for the assessment of frozen-thawed semen quality. Pronounced changes in DNA methylation may in part explain low fertility of semen that otherwise meets quality criteria analyzed by routine laboratory parameters. This suggestion is in agreement with the fact that aberrant sperm DNA methylation contributes to failure in fertilization and embryonic development [9-11]. In contrast, DNA methylation was not affected by shock-freezing of spermatozoa in liquid nitrogen $\left(-196^{\circ} \mathrm{C}\right)$ in the absence of cryoprotectiva while this treatment seriously impaired spermatozoa function determined by motility and membrane integrity. In agreement with our findings, DNA methylation was also not affected by shock freezing in other tissues, e.g., breast cancer tissue [25].

To date, there is some confusion whether defects in DNA methylation patterns observed in infertile individuals or

Table 1

Total motility (\%), progressive motility (\%), membrane intact spermatozoa (\%), morphologically intact spermatozoa (\%), and DNA methylation (\%) in semen before freezing and in thawed semen that was frozen either with Ghent or BotuCrio extender.

\begin{tabular}{|c|c|c|c|c|}
\hline Parameter & Before freezing & Ghent & BotuCrio & Significant effects \\
\hline Stallions (n) & 6 & 6 & 6 & - \\
\hline Ejaculates (n) & 18 & 18 & 18 & - \\
\hline Total motility (\%) & $88.8 \pm 1.4^{\mathrm{a}}$ & $69.5 \pm 2.0^{\mathrm{b}}$ & $68.4 \pm 2.2^{\mathrm{b}}$ & $\begin{array}{l}\text { Processing: } \mathrm{P}<0.001 \\
\text { Stallion: } \mathrm{P}<0.01 \\
\text { Processing } \times \text { stallion: } \mathrm{n} . \mathrm{s}\end{array}$ \\
\hline Progressive motility (\%) & $78.6 \pm 2.0^{\mathrm{a}}$ & $58.1 \pm 1.9^{b}$ & $57.2 \pm 2.2^{\mathrm{b}}$ & $\begin{array}{l}\text { Processing: } \mathrm{P}<0.001 \\
\text { Stallion: } \mathrm{P}<0.01 \\
\text { Processing } \times \text { stallion: } \mathrm{n} . \mathrm{s}\end{array}$ \\
\hline Membrane intact spermatozoa (\%) & $89.3 \pm 1.3^{\mathrm{a}}$ & $57.9 \pm 1.9^{b}$ & $57.0 \pm 2.2^{b}$ & $\begin{array}{l}\text { Processing: } \mathrm{P}<0.001 \\
\text { Stallion: } \mathrm{P}<0.05 \\
\text { Processing } \mathrm{x} \text { stallion: } \mathrm{n} . \mathrm{s}\end{array}$ \\
\hline Morphologic intact spermatozoa (\%) & $52.9 \pm 2.4^{\mathrm{a}}$ & $41.3 \pm 1.9^{c}$ & $43.9 \pm 1.7^{b}$ & $\begin{array}{l}\text { Processing: } \mathrm{P}<0.001 \\
\text { Stallion: } \mathrm{P}<0.001 \\
\text { Processing } \times \text { stallion: } \mathrm{P}<0.05\end{array}$ \\
\hline DNA methylation (\%) & $0.6 \pm 0.1^{\mathrm{a}}$ & $6.4 \pm 3.7^{b}$ & $4.4 \pm 1.5^{\mathrm{b}}$ & $\begin{array}{l}\text { Processing: } \mathrm{P}=0.01 \\
\text { Stallion: } \text { n.s. } \\
\text { Processing } \times \text { stallion: n.s. }\end{array}$ \\
\hline
\end{tabular}

Abbreviation: n.s., not significant.

Values are means \pm standard error of mean. Values with different superscripts within the same line differ significantly $(P<0.05)$ from each other. 
Table 2

Correlations among total motility (\%), progressive motility (\%), membrane intact spermatozoa (\%), morphologically intact spermatozoa (\%), and DNA methylation (\%) assessed in semen before freezing and thawed semen that was frozen either with Ghent or BotuCrio extender (total $\mathrm{n}=54$ samples).

\begin{tabular}{|c|c|c|c|c|}
\hline Parameter & Progressive motility & $\begin{array}{l}\text { Membrane intact } \\
\text { spermatozoa }\end{array}$ & $\begin{array}{l}\text { Morphologically intact } \\
\text { spermatozoa }\end{array}$ & DNA methylation \\
\hline Total motility & $\mathrm{R}=0.976 ; \mathrm{P}<0.001$ & $\mathrm{R}=0.966 ; \mathrm{P}<0.001$ & $\mathrm{R}=0.593 ; \mathrm{P}<0.001$ & $\mathrm{R}=-0.141 ; \mathrm{P}=0.309$ \\
\hline Progressive motility & & $\mathrm{R}=0.059 ; \mathrm{P}<0.001$ & $\mathrm{R}=0.641 ; \mathrm{P}<0.001$ & $\mathrm{R}=-0.120 ; \mathrm{P}=0.387$ \\
\hline Membrane intact spermatozoa & & & $\mathrm{R}=0.620 ; \mathrm{P}<0.001$ & $\mathrm{R}=-0.099 ; \mathrm{P}=0.476$ \\
\hline Morphologically intact spermatozoa & & & & $\mathrm{R}=-0.011 ; \mathrm{P}=0.936$ \\
\hline
\end{tabular}

after semen cryopreservation are characterized by hypermethylation [12,26-29], by hypomethylation of specific loci $[26,30]$ or whether disorders in both directions occur which result in no overall trend in global methylation [10]. Most probably, any change in DNA methylation needs to be considered critical. In the present study, sperm DNA methylation was determined with an ELISA specific for 5-methylcytosine. A more specific assessment of DNA methylation e.g., in imprinted genes could provide additional results. In humans, it has recently been demonstrated that global cytosine methylation in spermatozoa is highly reduced in comparison with leukocyte DNA [31]. No such information is available for the horse so far.

The ejaculates included into this study were in the physiological range for healthy Shetland pony stallions with regard to semen volume, concentration, total sperm count, and semen motility [17]. It is well-known that classical laboratory parameters in cryopreserved semen and the quality of frozen-thawed semen are very much influenced by the individual semen donor [3,4]. However, no statistically significant effect of the stallion on DNA methylation was detected, despite a high variation of DNA methylation levels among ejaculates. In some stallions (i.e. \#2, 3, and 6) which formed the group of old stallions ( $>20$ years) DNA methylation increased considerably especially when semen was frozen with $\mathrm{BC}$ extender. This suggests an increased susceptibility of semen from older stallions to undergo DNA methylation as it was shown in humans [32]. Highest mean DNA methylation in frozenthawed semen was detected in stallion \#1, which was only 8-year old. Interestingly, his ejaculates consistently did not meet the criteria recommended for cryopreservation of stallion semen [33], and sperm concentration was always less than $200 \times 10^{6} / \mathrm{mL}$. Low semen concentration corresponds with a high content of seminal plasma, which is an important factor for freezability of stallion semen [34]. Effects of seminal plasma components on DNA methylation during the cryopreservation process of stallion semen are therefore suggested.

In the present study, neither classical laboratory parameters nor DNA methylation were influenced by composition of the cryoextender. Although Ghent (G) extender contains only glycerol as cryoprotectant [35], BC extender contains a combination of glycerol and methylformamide [36]. Freezing extenders with amides as cryoprotectant have been suggested to improve the quality and fertility of frozen-thawed semen [36]. Nevertheless, more remarkable improvements have been reported to occur in stallions with poor semen quality after cryopreservation in the presence of glycerol alone $[8,36]$.
Because all stallions in the present study had an above-average quality of frozen-thawed semen when characterized by classical laboratory parameters, the lack of differences between semen frozen with G or BC is not surprising. There was also no overall difference with regard to DNA methylation with exception for stallion \#1, which showed a higher methylation of sperm DNA after cryopreservation with $G$ than with BC. A better fertility of equine semen frozen with methylformamide may not necessarily depend on differences in cytosine methylation of sperm DNA, but is rather due to prolonged viability of spermatozoa in the female genital tract [36]. Nevertheless, repetition of the present study in stallions with low cryosurvival of sperm and the inclusion of additional tests for DNA methylation could provide different results. In the case of boar semen, generally characterized by high sensitivity to cryopreservation, modifications of the cryopreservation protocol also affected gene expression of epigenetic markers for sperm DNA [12].

\subsection{Conclusions}

In stallions, cytosine methylation of sperm DNA is low in raw semen, but significantly increased in frozen-thawed semen. DNA methylation is not correlated to semen parameters evaluated by traditional laboratory tests. Reduced fertility of mares after insemination with frozenthawed semen may at least in part be explained by methylation of sperm-DNA, which occurs in response to the cryopreservation procedure.

\section{Competing interests}

The authors do not report any conflicts of interest.

\section{References}

[1] Aurich JE, Aurich C. Developments in European horse breeding and consequences for veterinarians in equine reproduction. Reprod Domest Anim 2006;41:275-9.

[2] Aurich JE. Artificial insemination in horses-more than a century of practice and research. J Equine Vet Sci 2012;32:458-62.

[3] Loomis PR, Graham JK. Commercial semen freezing: individual male variation in cryosurvival and the response of stallion sperm to customized freezing protocols. Anim Reprod Sci 2007;105:119-28.

[4] Pena FJ, Macias Garcia B, Samper JC, Aparicio IM, Tapia JA, Ortega Ferrusola C. Dissecting the molecular damage to stallion spermatozoa: the way to improve current cryopreservation protocols? Theriogenology 2011;76:1177-86.

[5] Amann RP, Pickett BW. Principles of cryopreservation and a review of cryopreservation of stallion spermatozoa. J Equine Vet Sci 1987; 145-73.

[6] Morris GJ, Faszer K, Green JE, Draper D, Grout BW, Fonseca F. Rapidly cooled horse spermatozoa: loss of viability is due to osmotic 
balance during thawing, not intracellular ice formation. Theriogenology 2007;68:804-12.

[7] Gutiérrez-Cepeda L, Fernández A, Crespo F, Ramírez MA, Gosálvez J, Serres C. The effect of two pre-cryopreservation single layer colloidal centrifugation protocols in combination with different freezing extenders on the fragmentation dynamics of thawed equine sperm DNA. Acta Vet Scand 2012;54:72-9.

[8] Gibb Z, Morris LHA, Maxwell WMC, Grupen CG. Dimethyl formamide improves the postthaw characteristics of sex-sorted and nonsorted semen. Theriogenology 2013;79:1027-33.

[9] Benchaib M, Ajina A, Lornage J, Niveleau A, Durand P, Guérin JF. Quantification by image analysis of global DNA methylation in human spermatozoa and its prognostic value in in vitro fertilization: a preliminary study. Fertil Steril 2003;80:947-53.

[10] Poplinski A, Tüttelmann F, Kanber D, Horsthemke B, Gromoll J. Idiopathic male infertility is strongly associated with aberrant methylation of MEST and IGF2/H19 ICR1. Int J Androl 2010;33: 642-9.

[11] Verma A, Rajput S, De S, Kumar R, Chakravarty AK, Datta TK. Genome-wide profiling of sperm DNA methylation in relation to buffalo (Bubalus bubalis) bull fertility. Theriogenology 2014;82: 750-9.

[12] Zeng C, Peng W, Ding L, He L, Zhan Y, Fang D, et al. A preliminary study on epigenetic changes during boar spermatozoa cryopreservation. Cryobiology 2014;69:119-27.

[13] Urrego R, Rodriguez-Osorio N, Niemann H. Epigenetic disorders and altered gene expression after use of assisted reproductive technologies in domestic cattle. Epigenetics 2014;9:803-15.

[14] Reik W, Dean W, Walter J. Epigenetic reprogramming in mammalian development. Science 2001;293:1063443.

[15] O'Doherty AM, McGettigan PA. Epigenetic processes in the male germline. Reprod Fertil Dev 2015;27:725-38.

[16] Comerford KL, Love CC, Brinsko SP, Edmond AJ, Waite JA, Teague SR, et al. Validation of a commercially available fluorescence-based instrument to evaluate stallion spermatozoa concentration. Anim Reprod Sci 2008;107:316-7.

[17] Deichsel K, Pasing S, Erber R, Ille N, Palme R, Aurich J, et al. Increased cortisol release and transport stress do not influence semen quality and testosterone release in pony stallions. Theriogenology 2015;84: 70-5.

[18] Pagl R, Aurich JE, Müller-Schlösser F, Aurich C. Comparison of an extender containing defined milk protein fractions with a skim milk-based extender for storage of equine semen at $5-8{ }^{\circ} \mathrm{C}$. Theriogenology 2006;66:1115-22.

[19] Schäfer-Somi S, Aurich C. Use of a new computer-assisted sperm analyzer for the assessment of motility and viability of dog spermatozoa and evaluation of four different semen extenders for predilution. Anim Reprod Sci 2007;102:1-13.

[20] Heckenbichler S, Deichsel K, Peters P, Aurich C. Quality and fertility of cooled-shipped stallion semen at the time of insemination. Theriogenology 2011;75:849-56.
[21] Schrammel N, Deichsel K, Aurich J, Aurich C. A long-day light program accelerates seasonal coat changes but is without effect on semen and metabolic parameters in Shetland pony stallions. Theriogenology 2016;85:946-53.

[22] Hancock JL. The morphology of boar spermatozoa. JR Microsc Soc 1956;76:84-97.

[23] Einarsson S, Dalin A-M, Lundeheim N. Sperm production and sperm morphology of Swedish warmblood stallions. Reprod Domest Anim 2009;44:33-6.

[24] Weyrich A. Preparation of genomic DNA from mammalian sperm. Curr Protoc Mol Biol 2012 Chapter 2:Unit 2.13.1-3.

[25] Wang Y, Zheng H, Chen J, Zhong X, Whang Y, Wang Z, et al. The impact of different preservation conditions and freezing-thawing cycles on quality of RNA, DNA, and proteins in cancer tissue. Biopreserv Biobank 2015;13:335-47.

[26] Hammoud SS, Purwar J, Pflueger C, Cairns BR, Carrell DT. Alterations in sperm DNA methylation patterns at imprinted loci in two classes of infertility. Fertil Steril 2010;94:1728-33.

[27] Navarro-Costa P, Noguiera P, Carvalho M, Leal F, Cordeiro I, Calhaz-Jorge C, et al. Incorrect DNA methylation of the DAZL promoter $\mathrm{CpG}$ island associates with defective human sperm. Hum Reprod 2010;25:2647-54.

[28] Nanassy L, Carrell DT. Analysis of the methylation pattern of six promoters in sperm of men with abnormal protamination. Asian J Androl 2011;13:342-6.

[29] Barzideh J, Scott RJ, Aitken RJ. Analysis of the global methylation status of human spermatozoa and its association with the tendency of these cells to enter apoptosis. Andrologia 2013;45:424-9.

[30] Boisonnas CC, El Abdalaoui H, Haelewyn V, Fauque P, Dupont JM, Gut I, et al. Specific epigenetic alterations of IGF2-H19 locus in spermatozoa from infertile men. Eur J Hum Genet 2010;18:7380.

[31] Guz J, Gackowski D, Foksinski M, Rozalski R, Olinski R. Comparison of the absolute level of epigenetic marks 5-methylcytosine, 5-hydroxymethylcytosine, and 5-hydroxymethyluracil between human leukocytes and sperm. Biol Reprod 2014;91:1-5.

[32] Jenkins TG, Aston KI, Pflueger C, Cairns BR, Carrell DT. Age-associated sperm DNA methylation alterations: possible implications in offspring disease susceptibility. PLoS Genet 2014;10:e1004458.

[33] Sieme H. Freezing semen. In: McKinnon AO, Squires EL, Vaala WE, Varner DD, editors. Equine Reproduction. Second edition. Chichester, UK: Wiley-Blackwell; 2011. p. 2972-82.

[34] Aurich JE, Kühne A, Hoppe H, Aurich C. Seminal plasma affects membrane integrity and motility of equine spermatozoa after cryopreservation. Theriogenology 1996;46:791-7.

[35] Martin JC, Klug E, Günzel-Apel AR. Centrifugation of stallion semen and its storage in large volume straws. J Reprod Fertil Suppl 1979; 27:47-51.

[36] Alvarenga MA, Papa FO, Landim-Alvarenga FC, Medeiros ASL. Amides as cryoprotectants for freezing stallion semen: a review. Anim Reprod Sci 2005;89:105-13. 